\title{
SUBSIDIES TO LESS FAVOURED AREAS IN THE CZECH REPUBLIC: WHY DO THEY MATTER?
}

\section{Jana Poláková*}

\begin{abstract}
Subsidy to less favoured area (LFA) farms is central to rural development policy in the European Union. Here, three categories of LFA support are assessed: farm competitiveness measures, LFA measures, and agri-environment measures. These categories of measures are complementary to safeguarding land management and delivering ecosystem benefits. Based on historical data for the Czech Republic, this paper endeavours to illustrate potential methods for assessing the LFA subsidies. In sum, rigorous methods to evaluate LFA evidence are still at their very starting point, even as they are necessary in order to ascertain the Community's capability, alongside the local, regional, or national institutional capability. A positive trend has been identified with regard to stabilizing the available rural development budget for the policy priority "Restoring, preserving and enhancing agroecosystems".
\end{abstract}

Keywords: LFA support, rural development funding, land-based measures

JEL Classification: Q10, N50, R1, H41

\section{Introduction}

Funding to land-based measures for farms in less favoured areas (LFAs) is drawn through the so-called multiannual financial framework of the EU rural development policy. Ample literature has evaluated impacts of using rural development funds in relation to the competitiveness of agriculture especially in mountain and foothill regions (Barnes et al., 2011; Kowalczyk et al., 2014; Vrolijk, 2009). The initial (and partly continuing) aim of LFA payments has been, since the launch of the LFA scheme in coeval Member States in 1975, to ensure stability for farmers' incomes by adding to their direct farm subsidies in response to the context of variable market factors and environmental conditions and thereby prevent a cessation of agriculture in such areas. Outwardly, societal concern with stagnation of rural economies and the role of support policies in social innovation has not only been studied by academics (Dwyer, 2016), but has also been shown as a factor in the unfolding of Brexit (Matthews, 2016a). LFA measures are important for maintaining public goods as cultural assets in relation to agricultural landscapes with their socioeconomic aspects (Vrolijk et al., 2009), next to biophysical factors (Cooper et al., 2006 and 2009; Madureira et al., 2013; Santos et al., 2016; Wrbka, 2004). Evidence exists that both traditionally oriented and

* Jana Poláková, Faculty of Agrobiology, Food and Natural Resources, Czech University of Life Sciences, Prague, Czech Republic (jpolakova@af.czu.cz).

Support under the Institutional Support Programme for long-term conceptual development of a research institution of the Ministry of Education, Youth and Sports of the Czech Republic is gratefully acknowledged. 
innovative farm businesses in LFAs have potential to ensure land management that is beneficial to biodiversity in comparison to farmers who are highly production-oriented but support the lowest nature values on their land (Anon, 2014; Barnes et al., 2011; Cardwell, 2004; Cudlínová et al., 2012; Schmitzberger et al., 2005). In particular, rural development policy has promoted the concomitant role of education and vocational training because public goods cannot be delivered without the necessary farming capacity being in place.

LFA subsidy was central to the fairly complex land-based measures in place during the period 2001-2006. These measures distinguished between regions that, depending on the level of disadvantages in relation to rural economies, had received support from the Guarantee section of the European Agricultural Fund for Rural Development, and regions that had been covered by the Guidance section of that fund (Commission of the European Communities, 2007). Both the Guidance and the Guarantee sections are related to the spheres of rural development budget as per Council Regulation (EC) No. 1257/1999. The financing of the so-called "horizontal" rural development measures for LFAs in the Czech Republic thus kicked off in 2004 in parallel with the provision of similar financing in nine other accession countries. The support was provided under the fund allocation referred to as the Temporary Rural Development Instrument, or "TRDI". The rural development measures for the period 2001-2006 also saw the beginning of GAEC implementation in 2005. Subsidies to LFA farmers in the Czech Republic date back to the late 1990s, when national assistance was allocated to the maintenance of permanent grasslands in mountain areas. Since 2004 and 2007, EU funds have become available for the three categories of LFA measures. Subsidies for competitiveness, LFA payments, and agri-environment measures were set out in the Horizontal Rural Development Plan 2004-2006 and the Rural Development Programme 2007-2013. The LFA payments have targeted maintenance of permanent grasslands.

With respect to the period 2014-2020, on the basis of eight common biophysical criteria, a redefinition of geographic targeting for LFA subsidies is ongoing in order to overcome earlier criticisms alleging that such payments were insufficiently effective (Cooper et al., 2006; Keenleyside et al., 2012). To date, there remains a need for more comprehensive evidence of the role of LFA support, not just with regard to the implicit assumption of the continuation of agricultural activity to be part of the counterfactual reference line, i.e., part of the hypothetical situation of what would have happened in the absence of public support.

The aim of this article is to evaluate LFA support outcomes for the period 2001-2013 while examining detailed evidence from the Czech Republic on the one hand, and the summary funding data at the EU level on the other hand. The specific goal in relation to the Czech Republic data is to assess each category of LFA support within the time frame 1998-2013. Moreover, we estimate the 2017-level of subsidy for each category. Why LFA support matters to land managers, we hypothesize here, is that the confluence of the three funding categories enhances the farmers' negotiating positions in rural economies under globally driven factors. 


\section{Material and Methods}

\subsection{Primary data}

Primary information relating to budget allocations for rural development in the Czech Republic came from the library at the country's Institute of Agricultural Economics and Information. It includes data in relation to LFA support for three categories of LFA measures: farm competitiveness, LFA payments, and the agri-environment. These funding data have been complemented, where appropriate, with content-related information in relation to administrative tools through which LFA subsidies have been implemented, i.e., national assistance prior to 2004, the Horizontal Rural Development Plan for the period 2003-2006, and the Rural Development Programme for the period 2007-2013. Additional data were collected via the electronic library of the Commission of the European Communities. The majority of the information came from the annual datasets provided by reports by the Directorate-General Budget (1999, 2006-2013). Complementary data originate from the Directorate-General for Agriculture and Rural Development (Commission of the European Communities, 2007).

\subsection{Study area}

The role of LFA support at the EU level was estimated only partially, by complementing the national-level data for the Czech Republic with selected data as regards BelgiumFlanders, Belgium-Wallonia, Portugal-Mainland and UK-England, in addition to the freely available data at the EU level.

Table 1 | Structure of agriculture in the Czech Republic in 2011, with share of holding types within size classes in hectares, Agricultural Area (UAA), and the share of farms within each class being classified as legally established companies

\begin{tabular}{|l|r|r|r|r|r|r|r|r|r|}
\hline & \multicolumn{1}{|c|}{$\boldsymbol{\Sigma}$} & \multicolumn{1}{c|}{$\mathbf{2}$} & $\mathbf{2 - 4 . 9}$ & $\mathbf{5 - 9 . 9}$ & $\mathbf{1 0 - 1 9}$ & $\mathbf{2 0 - 2 9}$ & $\mathbf{3 0 - 4 9}$ & $\mathbf{5 0 - 9 9}$ & $>\mathbf{1 0 0}$ \\
\hline Area & $3,491,470$ & 2,390 & 5,920 & 34,790 & 64,040 & 56,680 & 90,730 & 171,470 & $3,065,450$ \\
\hline Numbers & 100.0 & 31.9 & 16.2 & 11.4 & 10.2 & 5.4 & 5.9 & 5.9 & 10.8 \\
\hline UAA & 100.0 & 0.3 & 0.5 & 0.9 & 1.6 & 1.5 & 2.5 & 4.6 & 88.1 \\
\hline $\begin{array}{l}\text { Legal } \\
\text { companies }\end{array}$ & 0.6 & 1.3 & 2.0 & 2.7 & 2.8 & 5.6 & 6.5 & 48.1 & - \\
\hline
\end{tabular}

Source: Eurostat (2011).

The structure of LFA farms in the Czech Republic differs between family farms and cooperatives linked to ruminant livestock systems. This structure is not identical to subsistence farming, as researched for Mediterranean silvo-pastoral systems by PintoCorreia et al. (2016), or family cooperatives, as examined by Nadal-Romero (2013). The size categories in hectares for the Czech Republic LFA farms are comparatively close 
to the agriculture structure generally, where large farms prevail (Table 1). This distributive aspect may be linked to the evolution before the economic transformation of agriculture in 1992. Up to 1992, large cooperatives farmed areas of around 2476 ha on average, covering about two thirds of the overall agricultural area. In comparison, state enterprises farmed 7650 hectares on average, amounting to around one fifth of the overall agricultural area. Subsistent rural households maintained the rest of farmland. With the shift to market economy, the legal status of the farms changed to cooperatives, private limited companies, joint-stock companies, and family farms owned by natural persons. Urban dwellers who gained an effective individual title to farmland, although not all, tended to lease land to legal successors of the earlier cooperatives.

\subsection{Methods}

In a first step, the effect of temporal distribution of LFA funds among the above three categories was tested in respect of the Czech Republic support measures with an analysis of variance (ANOVA), using the Statistica software (Statistica Development Core Producers 2014, version 2.15.9). Consequently, three categories of subsidies were discussed, with regard to the established factors of linearity, homogeneity and distant (less probable, "outlying") values, in light of several explanatory variables.

Explanatory variables are so-called qualitative factors which help to grasp why the data look the way they do in temporal succession. Several classes of explanatory variables cropped up. One of the explanatory factors is political decisions, e.g., in respect of how many calls for applications were set up in the individual years or over the programming cycle for each measure. Another explanatory variable was credited to be time requirements for processing applications submitted in respect of the call and time to sign off the grants in relation to farm-competitiveness investments or agri-environment agreements. Plausible though less easy to research is the factor of farmer union pressures, which may have resulted in shifting the funds either to the beginning or the ending of the programming period. Finally, staff capacity, not excluding staff taking a break from setting up more calls for applications when existing projects already funded reach the peak implementation phase, is an explanatory variable taken into account.

The explanatory variables set out above were screened for practicality and the first named variable was quantitatively transformed into marks using 0 (absence, when in the individual year there were less than two calls for applications within the measure) and 1 (presence, when more than two calls for applications could be found within the year). The explanatory variables were prepared for three temporal intervals, 1998-2004, 2004-2010, 2011-2013, with each value checked for significance as regards $\mathrm{P}=0.05$, although it was clear from the beginning the a 15 -year-long data sequence with a yearly step is insufficient for finding a proper statistical proof of dependency. Finally, simple correlation tables were reinstate to support each value of the factor with regard to linearity, homogeneity and distant, less probable, "outlying" values. Such tables were evaluated so as to be able to point out a few incomplete answers for LFA fund implementation over time. 
These may be interesting to scientists who strive to grasp why it mattered to establish a more or less formal status for a de facto LFA measure; whether the measures ease negotiations of funds over time; or how the impact of the measures can be evaluated to see its successfulness.

\section{Results}

\subsection{Less favoured area support: the Czech Republic data}

Support to LFA farmers in the Czech Republic saw the onset of disbursement as implementation of three measures: LFA subsidy, agri-environment payments (supporting more advanced voluntary commitments in relation to grasslands), and farm competitiveness measures (Figure 1). Considering the LFA subsidy alone, it has contributed around three-quarters of gross farm income in mountain area farms. Figure 2 shows the increase in funding to the three categories of measures.

Figure 1 | Yearly allocation of payments to LFA farms in three categories of support - farm competitiveness, LFA payments, and agri-environment in 1998-2013

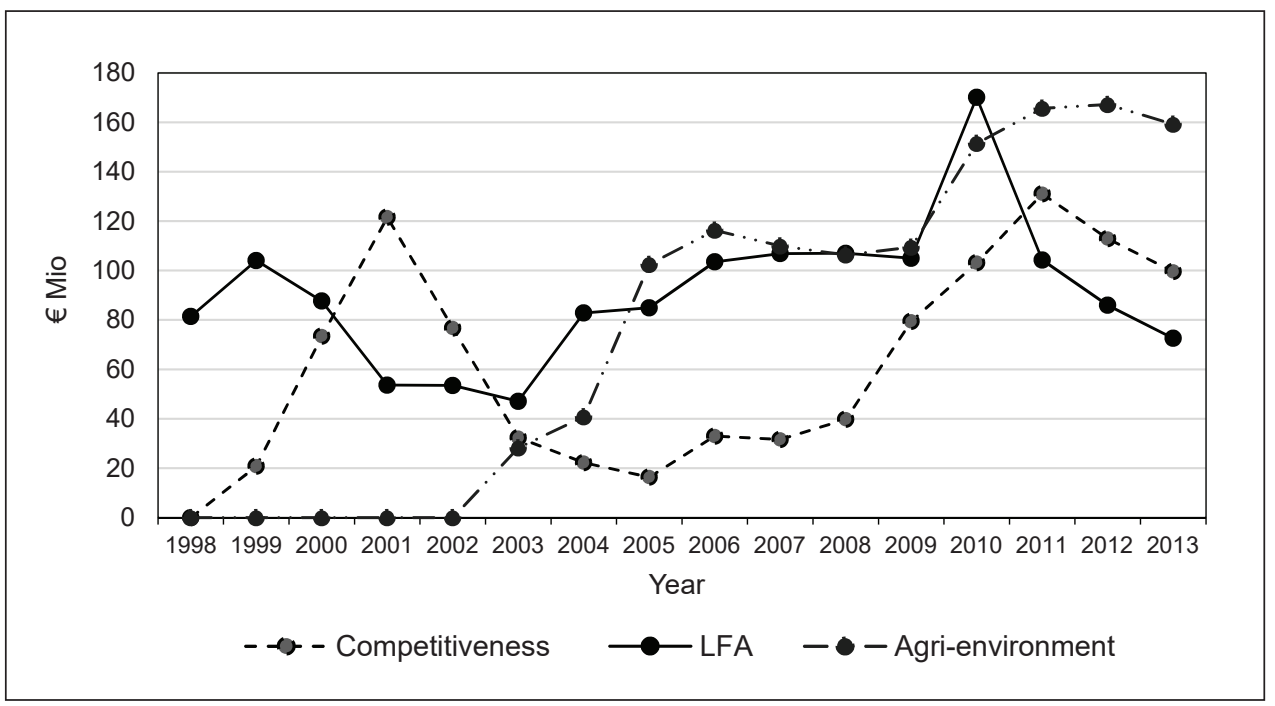

Source: Ministry of Agriculture (1998-2013).

It is clearly unfeasible to seek to extricate solid cause-effect links. It is nevertheless plausible to strive to tease out several correlations linked to the factors affecting financial disbursement over time, e.g., the number of calls for applications within a calendar year. It appears reasonable to set a threshold of two calls for applications per year as having a probable effect on the temporal disbursement of finance thereafter. Considering the time interval 1998-2004, one can ascertain the presence of two or more calls for applications only for the farm-competitiveness measures, whereas there were fewer calls in regard to LFA 
measures and agri-environment measures. Taking into account the time interval 2004-2010, we were able to note the presence of two or more calls for applications for each of the three categories of measures. However, in the time interval 2011-2013, a relatively limited time period, there was a notable absence of two or more calls for applications within each of the three measures.

Figure 2 | Trends of three categories of support - farm competitiveness (top), LFA payments (middle), and agri-environment (bottom) in 1998-2013

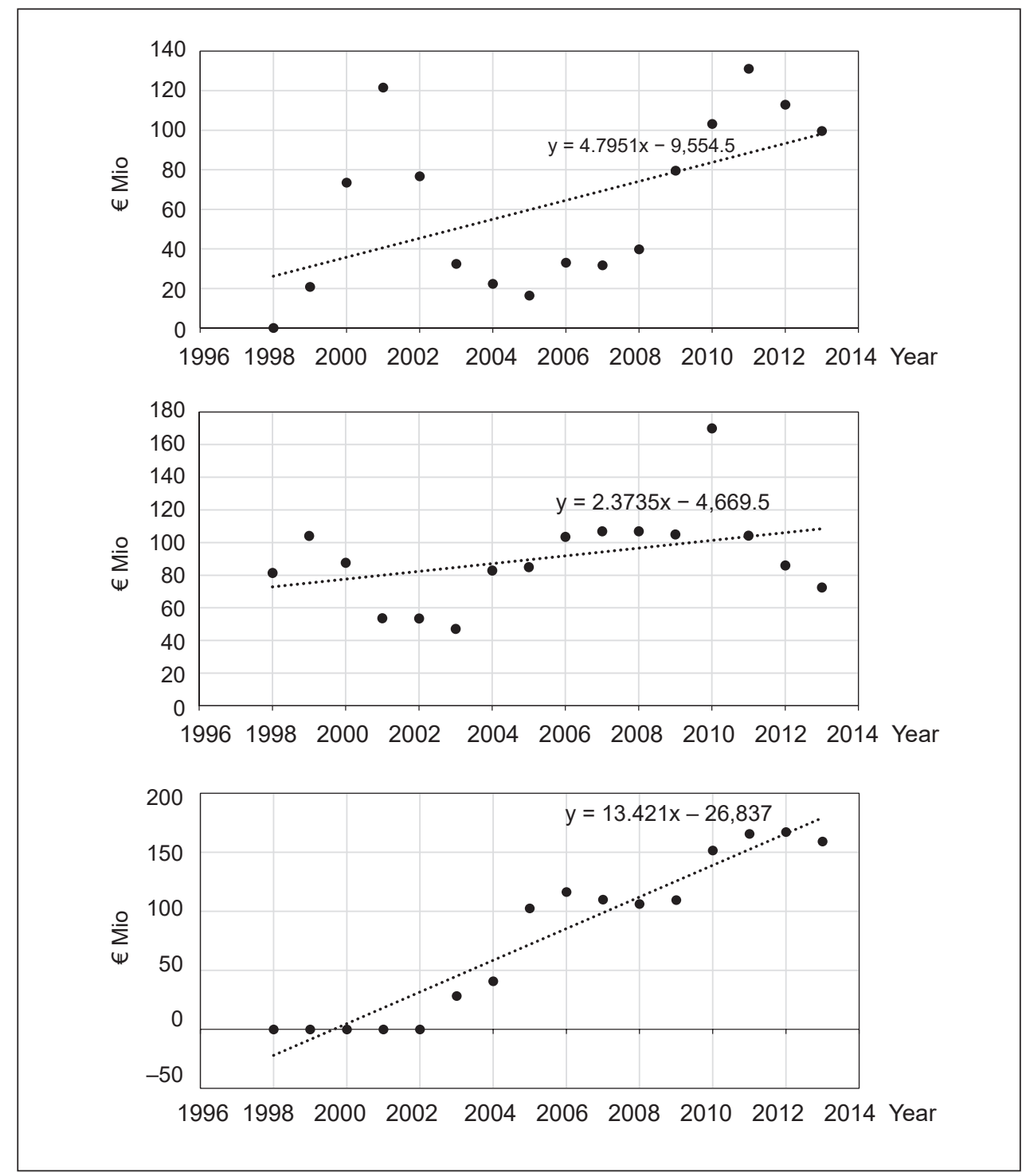

Source: Ministry of Agriculture (1998-2013). 
Herewith, starting from the indicators of presence/absence as discussed, we set to demonstrate problems trying to exclude all such intervening factors, particularly the unar-guably present effect of the political character of decisions involved in the fund distribution.

Table 2 | Correlation linking rural development outlays with each subsidy category to period of time

\begin{tabular}{|l|c|c|c|}
\hline & Farm competitiveness & LFA measures & Agri-environment \\
\hline 1998-2004 & + & - & 0 \\
\hline $2004-2010$ & + & + & + \\
\hline $2011-2013$ & - & - & - \\
\hline
\end{tabular}

Note: (+) high correlation; (-) low correlation, (0) insufficient data.

Source: Own compilation based on the online documents retrieved from https://www.szif.cz/en/ rdp_2007_2013

In the first step, our evaluation had to take into account linearity, although the data were relatively fragile to be able to state any solid conclusions for the first two time intervals. With regard to the 2011-2013 time interval, we could fairly clearly note yes, there is negative association, with a slow decrease in funds.

Secondly, the consideration of homogeneity yielded a no-answer with respect to the time interval 1998-2004. We could note, as regards 2004-2010, yes for LFA measures, as well as the agri-environment support, next to a slow increase in homogeneity with farm-competitiveness support.

Thirdly, we took into account distant values. In the time interval 1998-2004, there is a distant value linked to the LFA measures (the 1999 value), and one linked to the farmcompetitiveness measures (the 2001 value). In the period 2004-2011, it is possible to note distant values linked to farm-competitiveness support: 2005, 2011; one distant value with regard to LFA measures: 2010; with two further distant values in respect of agri-environment: 2009,2011 . It was impossible to qualify the time interval 2011-2013 due to a lack of data.

Table 3 | Actual and predicted values for three categories of support (farm competitiveness, LFA payments, agri-environment) in relation to LFA farms in 2011 and 2017

\begin{tabular}{|l|c|c|c|c|}
\hline & \multirow{2}{*}{$\begin{array}{c}\text { 2011 support } \\
\text { (€ Mio) }\end{array}$} & Predictions & $\mathbf{- 5 \%}$ & $\mathbf{+ 5 \%}$ \\
\cline { 3 - 5 } & 131.10 & 117.30 & 63.95 & 170.65 \\
\hline Farm competitiveness & 104.30 & 117.96 & 77.83 & 158.08 \\
\hline LFA payments & 165.70 & 232.91 & 204.19 & 261.64 \\
\hline Agri-environment & & &
\end{tabular}

Source: Ministry of Agriculture (1998-2013). 
We also checked whether the predicted values of support at the year +4 have no additional effect for producers because the support levels are already internalized within the production parameters at the farm level. Figure 2 shows the linear regression trends. Table 3 provides an overview of the calculated sums pertinent to the 2017 support to each category, including the limiting values within the probability interval from $+5 \%$ to $-5 \%$.

There is a paucity of scientific evaluations of the outcomes of the LFA support for the environment in the Czech Republic and the EU as well. Still, all the existing meta-evaluations emphasize the effect on avoidance of land abandonment in LFA regions (Tima s.r.o., 2010; Ministry of Agriculture, 2007, Ministry of Agriculture, 2009). It is generally known that the key drivers of agricultural abandonment are not only physical factors that limit yields and/or increase the costs of farming (e.g., poor soils). It is also economic factors such as low commodity prices and the availability of agricultural support via LFA measures (Keenleyside et al., 2012). In 2007, as a result of the implementation of the EU funds of the period 2000-2006 in the Czech Republic, 348.5 thousand hectares of grasslands benefited from LFA support in LFA-M regions, i.e., $115 \%$ of the planned indicator. In LFA-O regions (other than mountains), the figure was 394.6 thousand hectares, i.e., 99\% of the planned target. In 2015, the figures for the hectare indicator show a negligible upward difference.

A concurrent beneficial effect was noted, although not scientifically proved, for biodiversity. It is related to the continued agricultural use of high nature value grasslands, thereby avoiding the low-value woody plant successions that are likely to erode soils and grassland biodiversity. Little or no evidence exists for the theory of the benefits of land abandonment in croplands of the Central European region. This is notwithstanding the fact that for Southern Europe, cropland abandonment was found to be a complex phenomenon that might also have positive aspects for soils and biodiversity (Rodrigo-Comino et al., 2017). Both earlier and more recent sources (Cooper et al., 2006; IfLS, 2012; Ministry of Agriculture, 2016; Pelucha et al., 2013) are consistent in upholding the synergistic effect of the LFA support with the agri-environment and farm competitiveness measures, with plausible benefits for the environmental value of permanent grasslands.

\subsection{EU rural development funds to land-based measures for the period 2001-2006}

In assessing the relative funding commitment appropriations by the European Union and the local budgets, it should be noted that the anticipated budget to Rural Development Programmes accounted for just $8.17 \%$ of the EU budget for the period 2000-2006. That comes to $€ 8.7$ billion annually, with $€ 12.1$ billion being the anticipated financial support in 2006 (one year after the onset of GAEC implementation). The latter figure was almost double the amount of the anticipated support for meeting rural area needs in 2000 . The subsidy to farm competitiveness, LFA payments and the agri-environment jumped up especially in 2004, when the overall rural development spending amounted to $€ 10.3$ billion, one-third more than the year before. That leap is remarkable in view of the fact that financing of so-called "horizontal" rural development measures in the Czech Republic 
kicked off in 2004 together with similar financing in other EU Member States who followed the accession routine. Figure 3 and Figure 4 show the rather complex measures for the period 2000-2006 in relation to the needs of rural areas, which received support either from the Guarantee section or the Guidance section of the European Agricultural Fund for Rural Development, whilst comparing the Czech Republic data to the EU data. The figures seek to clarify the complexity resulting from Europe's effort to integrate rural development measures (under the Guidance section of funding) with the regional or territorial cohesion objectives (under the Guarantee funding section).

Figure 3 | EU rural development funding anticipation (left) and Czech Republic rural development commitment appropriation (right) for the years 2000-2006
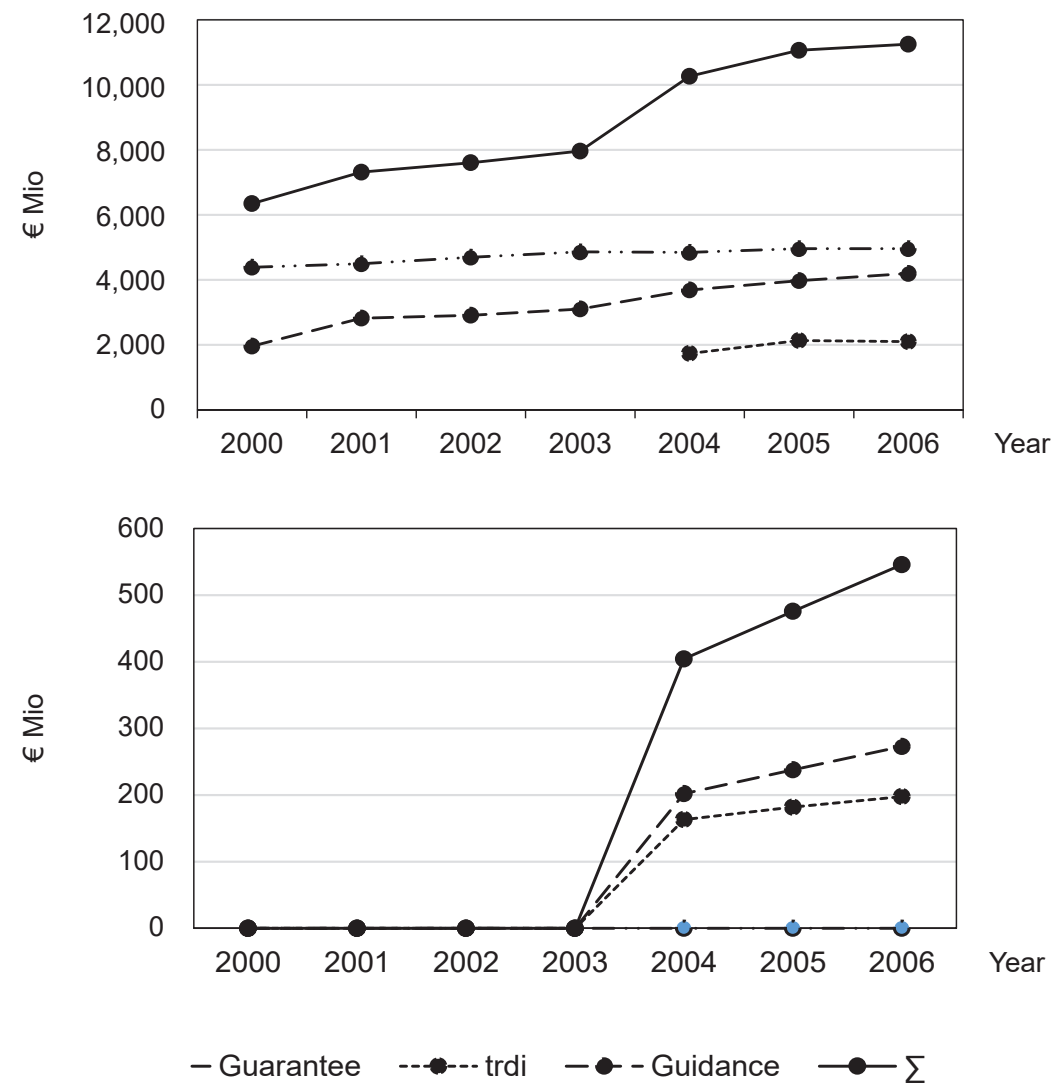

Note: Guidance / Guarantee are parts of the European Agricultural Fund for Rural Development; the Temporary Rural Development Instrument (trdi) relates to Horizontal Rural Development Plans

Source: DG Budget (2001-2007). 
Figure 4 | EU rural development expenditure (left) and Czech Republic rural development commitment expenditure (right) for the years 2000-2006
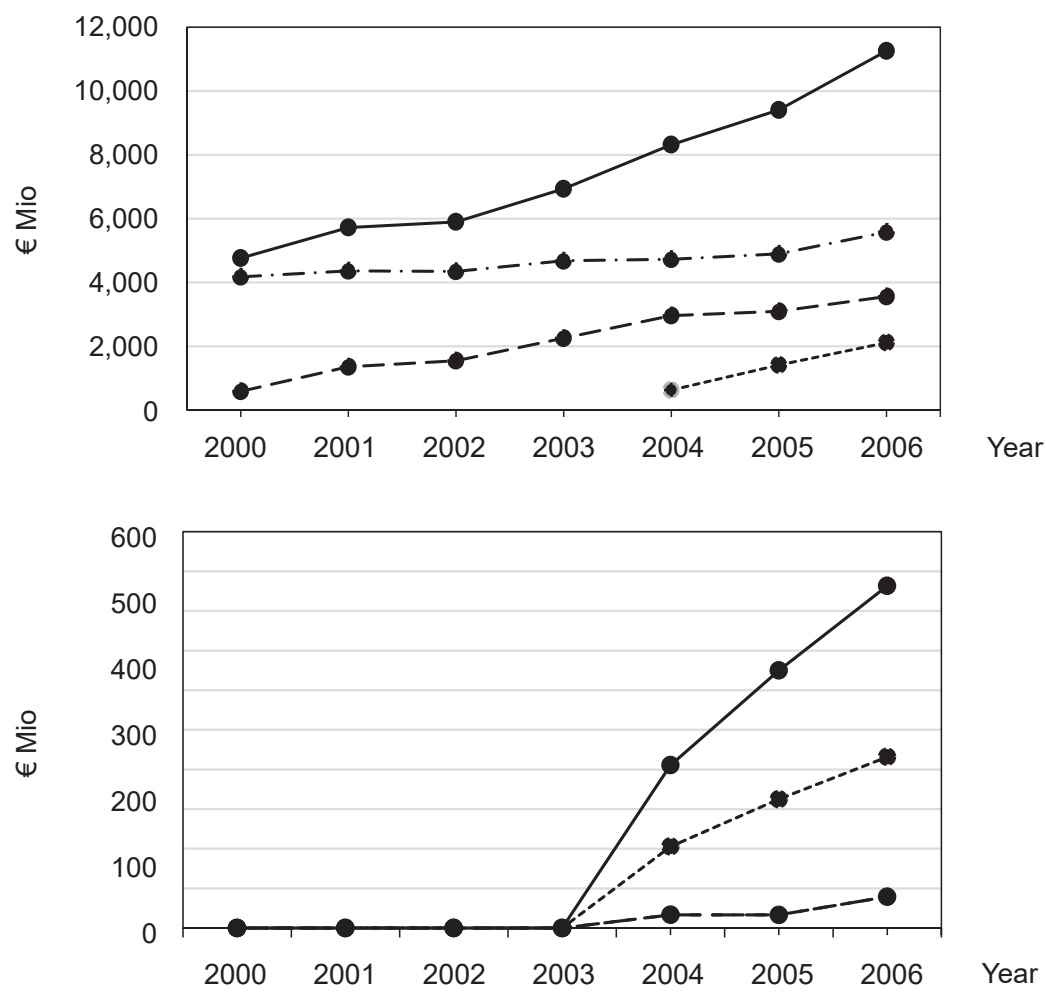

Note: Guidance / Guarantee are parts of the European Agricultural Fund for Rural Development; the Temporary Rural Development Instrument (trdi) relates to Horizontal Rural Development Plans

Source: DG Budget (2001-2007).

It is important to note that the financial data measuring success in relation to rural policy spending for the period 2000-2006 are available only up through 2005 . Since there is no single definition of success, here we have chosen to apply a conventional measure which is the intensity of commitment expenditure realized in comparison with the anticipated commitment at the period's beginning. Accordingly, the EU support (including for the 25 Member States), as expenditures actually made by 2005, accounts for around $67.1 \%$ of the anticipated commitment. The plausible intensity would be 6.5 percentage points higher when the period had drawn to a close, in 2006. When disaggregating this figure into its regional components relating to the years 2004-2005, the Czech Republic had used $€ 439.8$ million in anticipated rural development commitment while the EU had accordingly 
used $€ 21.3$ billion. These are huge amounts of money, yet this calculation probably masks varied outcomes for agroecosystems.

\subsection{EU rural development funds to land-based measures for the period 2007-2013}

The relative importance of the annual allocation to rural development in comparison to the respective annual assistance to land managers continued to grow year to year, albeit at a slower pace of approximately 2.7 points (compared to the aforementioned 11.7 points for the earlier planning period). Whereas the LFA payment category received $4.4 \%$ and $4.2 \%$ of the overall programmed expenditure for the ecosystem priority in, for example, BelgiumFlanders and UK-England, it was allocated considerably greater budgets in BelgiumWallonia, Portugal-Mainland, and the Czech Republic (18.8\%, 42.1\% and 40.2\%, respectively). Explanations might include cultural preference for implementing supports via agreement-based agri-environment payments in Belgium-Flanders, Belgium-Wallonia and UK-England (with $91 \%, 78.2 \%$ and $82.2 \%$ of the overall commitment going to the ecosystem priority) than in Portugal and the Czech Republic (with 31.4\% and 56.6\% allocations to the ecosystem priority going to the agri-environment category). Rural development policy support for the period 2007-2013 accounted for about one-fifth of Heading 2: Allocation to natural resource protection within the EU budget. Because the EU budget has adapted its structure over time, it is not easy to say whether this constitutes an evolving rural development subsidy to LFAs. In effect, the measure in relation to the importance of rural development policy (for the period 2007-2013), considered in terms of the average base proportion within Heading 2: Allocation to natural resource protection, is not fully compatible with the earlier average base (for the period 2001-2006). The earlier base was generally regarded as the remainder of the Agriculture heading after the deduction of aid to land managers, albeit not exclusively. In sum, efforts to compare rural development positioning in relation to Heading 2: Allocation to natural resource protection (applicable to the period 2007-2013) to the positioning in relation to the Agriculture category (applicable to the period 2000-2006) run up against considerable difficulties. For both, the base year proportion is approximately just $20 \%$ of the fund allocation, calculated with regard to the specific Heading 2, or the general category Agriculture. Moreover, these figures also mask a certain divergence in views as to the utility of rural development policy spending in favour of benefits to LFAs. The views reflect the tremendously high variability in the local, regional, national or EU allocations to protection of natural resources regarding the unit of the existing EU budget relevant to the individual Member State.

Macro-data for the ecosystem effects of agricultural practices in LFAs are sparse. Several EU-level evaluations exist (Cooper et al., 2006; Crabtree et al., 2003; Dwyer et al., 2016; Dax et al., 2016; IfLS, 2012). However, none of the projects aimed to assess coherently meta-data on ecosystem effects of LFA across the varied farm systems of the EU Member States. One of the outcomes of LFA support, whereby available data are consistent, is that farm practice in LFA regions is more environmentally friendly than in other areas. 
Where LFA farms uphold appropriate standards, their environmentally friendly practices mean, e.g., lower use of fertilisers and pesticides, but also a higher participation rate in agrienvironment measures (Rudow et al., 2014). The analysis based on data from Germany showed that the effect on the environment depends on the crop structures of farms, e.g., the share of maize and wheat in farms inside and outside the LFAs. Early reports (OECD, 2008) and unpublished data (Poláková et al., 2018) are more cautious, alerting to the possibility of adverse soil effects of inadequate practice. The European auditors (CoA, 2003) alerted the public about insufficient data with regard to ecosystem benefits of the LFA scheme at the EU level.

\subsection{Post-2013 changes}

In Rural Development Programmes, only minimal shifts in numbering the regulation articles, refocusing the overarching priorities relevant to farm competitiveness measures, LFA measures and agri-environment measures, were prompted by the 2014 policy reform (LorizHoffmann, 2011). The linear trend analysis has revealed that the annual support levels within the three named categories of support are likely to follow the moderately linear trends, as shown in Table 3. After the phasing in of the unified set of eight criteria based on nature sciences particularly relevant to climate, the potential for the fair allocation of LFA support is still under discussion.

\section{Discussion}

This paper analyses evidence in relation to rural communities impacted by LFA subsidies during the period 1998-2013 in the Czech Republic, doing so alongside the evidence offered with regard to several particular Member States for the time frame 2001-2013. It would be overambitious to seek to compare the selected Member State data in detail since such resources are presumed to exist in respective evaluation documents compiled by national authorities in national languages, thus being unavailable in detail at the EU level, where only the Commissions' total sums associated with the overall multiannual funds factsheets are available. With the existing work in the area in mind, novel in the present study is the focus on the detailed evaluation of the LFA support within the study area of the Czech Republic, whilst efforts are made to meaningfully compare the abovementioned comparative regional, national and European scales.

The study focused methodically on the evaluation of the financial indicator with regard to LFA support. The starting point of the assessment is in recognition of the fact that the evaluation of the outcomes of LFA support for the environment is seriously complicated since the Rural Development Programmes have not included an environmental indicator for the LFA support so far. Such economic focalization of the method is justified because of farm economy, farm viability and farm profitability being an important driver of a receding cultivation trend in structurally disadvantaged areas (Dax et al., 2000; LEI, 2010). The quantitative data were therefore the prior objective, complemented by qualitative measurements of the relevance of LFA support for ecosystem objectives in Europe and, above all, the Czech Republic. 
So, considering the relevant measures in support to farm competitiveness, LFA, and the agri-environment, they represent a considerable success thus far, although the time for which they have been implemented is still limited. In the policy cycle starting in 2015 , a positive trend has been identified with regard to stabilizing the available rural development budget for the policy priority "Restoring, preserving and enhancing agroecosystems". There has occurred a marginal strengthening from just over one-half of the overall budget (as regards 2007-2013) to around 66\% (regarding 2014 and beyond). This finding concurs, to an extent, with Firbank et al. (2013), who note that there exists abundant evidence of generally adequate quality and availability in regard to ecosystem benefits which are reduced as a consequence of inadequate farming practice (so-called ecosystem disservices). It is especially true in respect of water and air quality for the period starting in 1990, when the negative trends started to improve; yet there are not enough adequately solid data on the benefits of LFA farms, e.g., for water retention measures or flood control measures. The finding is also consistent with Barnes et al. (2011), who emphasized beneficial outcomes of preventing the cessation of agriculture in struggling regions with the least productive land. We are wary of the line of research whereby unclear production effects are ascribed to all agricultural subsidies; for instance, Rizov et al. (2013) or Kazukauskas et al. (2014) have generally found a negative relationship between farm support and farm productivity. However, this study is consistent with Tangermann (2011), who notes it is neither effective nor efficient to seek to incentivize farmers through support per hectare, particularly when support is not linked to local conditions under which they farm, and unrelated to the valuable public services required in their neighbourhood, an argument important in the present study.

Many farms (around one fifth) do not claim any support including LFA bonus, estimates Matthews (2016b). This farmland is therefore under scarcely any obligation to pursue mandatory environmental management standards (Cao et al., 2009, Dvorský et al. 2005, Jongeneel et al., 2005 and 2007). The present study thus supplements results by Meyers et al. (2012), who note the benefits to extensive farmland from LFA measures, whilst caution is voiced about untrivial expenses. The overall allocation to LFA farms amounts to 21 billion euros (the 2007-2013 period), thus making up 23\% of all expenditures on rural development in Europe (Meyers et al.). Matthews enumerates LFA support (the 2014-2020 period), together with agri-environment outlays, to 49\% of "total resources" in rural development plans.

It is undoubtedly an important question whether the use of ample resources allocated to LFA support actually leads to improved ecosystem services and state of the environment thanks to the land being continually cultivated. Evidence for this has been so far largely based on commissioned research for governmental authorities (at the EU level and in the Czech Republic), hence it is not easy to extricate bias. Therefore, the question of improved ecosystem services should become the subject of study with more scientific vigour.

Lately, the comparative study by Rutz et al. (2014) is consistent with the earlier discussion in scepticism with respect to the ongoing tightening of the criteria for delimiting LFA regions so as to achieve more efficient support. Keenleyside et al. (2012) and others criticized the chaotic multitude of many different criteria in use by Member 
States in delimiting the portion of their territory to be supported through LFA measures. In the present study, we did not aspire to a full comparative assessment, so we do not discuss which side of the debate is right.

The critical point is that the present exercise finds that the totality of these pieces of evidence has been necessary to document socioeconomic history in relation to LFA support. The results ascertain the increasing levels of support to LFA farms over time, in terms of both national-level and EU-level evidence, in addition to ascertaining the practical outcome of halting the semi-abandonment trend which affected around 300,000 hectares of permanent grassland in the Czech Republic during the 1990s. In contradistinction to Nikodemus et al. (2005) and Nadal-Romero et al. (2016), who monitored benefits of LFA farming for landscapes, water retention, and soils in individual regions, the present evaluation was able to highlight the importance of EU support in order to prevent negative effects for rural viability, which could unfold with cessation of LFA agriculture. From the evidence provided above, it is possible to state that approaches to LFA support, linked to GAEC practice in terms of safeguarding natural resources, economic budgets, and potentials, continue to be valid.

\section{Conclusions}

This paper endeavours to illustrate potential methods for assessing LFA support within the EU in order to demonstrate the critical aspects of analysing evidence at the national and EU levels. In that sense, the methodology enhances the initial approaches by Cooper et al. (2006). In conclusion, it can first be noted that rigorous methods to evaluate evidence with EU-wide applicability in relation to LFA support are still at their very starting point, even as they are necessary in order to ascertain the Community's capability, alongside the local, regional, or national institutional capability. Second, having assessed the overall allocation of resources to evolving LFA support in the policy cycle starting in 2015, a positive trend has been identified with regard to stabilizing the available rural development budget for the policy priority "Restoring, preserving and enhancing agroecosystems". There has occurred a marginal strengthening from just over one-half of the overall budget (as regards 2007-2013) to around 66\% (regarding 2014 and beyond). The impact of funds is utterly relevant given the existing evidence of farm economy being one of the key drivers of farmland abandonment, next to physical factors such as poor soils. The effects of abandonment for the environment outcomes, in the absence of LFA support, are not uniform, so it is a promising research avenue. It is of utmost importance to continue the efforts to develop scientific methods for assessing also the ecosystem effects of LFA support. Third, to ensure that the dedicated funds also contribute to functioning local knowledge in relation to LFA support, it is as pertinent as ever to enhance education and training directed to safeguarding natural resources in consideration of local, regional (or national) and EU economic circumstances. In sum, investigation may be worthwhile to answer how LFA farms will respond to the shift towards streamlined criteria, in the sense of farm and land management, and how they will affect macro-scale socioeconomic as well as ecosystem priorities or the structure of rural development support. 


\section{References}

Anon (2007). Rural Development Programme 2007-2013. Available at: http://eagri.cz/public/ web/mze/dotace/program-rozvoje-venkova-na-obdobi-2007/programove-dokumenty/ program-rozvoje-venkova-cr-puvodni.html

Barnes, A., Schwarz, G., Keenleyside, C., Thomson, S., Waterhouse, T., Polakova, J., Stewart, S., McCracken, D. (2011). Alternative Payment Approaches for Non-Economic Farming Systems Delivering Environmental Public Goods. Scottish Agricultural College, Institute for European Environmental Policy, Thünen Institute for Farm Economics.

Cao Y., Elliott, J., Jones, G., Simpson, D., Boatman, N., Laybourn, R., Northing, P., Ramwell, C., Turley, D., van Driel, K., Condlifee, I., Dennis, E., Dwyer, J., Mills, J. (2009). Evaluation of Cross Compliance. Report to Department of Environment, Farming and Rural Affairs (Defra), ADAS; Central Science Laboratory; University of Gloucestershire.

Cardwell, M. (2004). The European Model of Agriculture. Oxford: Oxford University Press. ISBN 978-0199242160

Commission of the European Communities (2007). Agriculture Statistics and Economic Information. Brussels: Commission of the European Communities.

Cooper, T., Baldock, D., Rayment, M., Kuhmonen, T., Terluin, I., Swales, V., Poux, X., Zakeossian, D., Farmer, M. (2006). An Evaluation of the Less Favoured Area Measure in the 25 Member States of the European Union. Brussels Report for Directorate-General Agriculture.

Cooper, T., Hart, K., Baldock, D. (2009). The Provision of Public Goods through Agriculture in the European Union. Brussels: Directorate-General Agriculture. [CoA] Court of Auditors (2003). Report No. 4/2003. Rural Development Support for Less-Favoured Areas. Luxembourg: Court of Auditors of the EU.

Crabtree, B. (2003). The Review of Area-based Less Favoured Area Payments across EU Member States. A report for the Land Use Policy Group.

Cudlínová E., Lapka, M. (2012). An Environmental Society? Concepts, Policies, Outcomes. Prague: Karolinum Press. ISBN 978-8024620923.

Dax, T., Hellegers, P. (2000). Policies for Less Favoured Areas. Chapter 11, in Brouwer, F., Lowe, P., eds., CAP Regimes and the Countryside. Newcastle: CABI Publishing. ISBN 9788-0851993546.

Dax, T., Copus, A. (2016). Research for AGRI Committee - Rural Development Policy. Brussels: European Parliament. ISBN 978-9284601912.

Directorate General Budget (1999, 2000 to 2013). EU Budget Report. Brussels:

Commission of the European Communities.

Dvorský, J., Jelínek, A., Koutná, K., Mana, V., Semrád, Z., Smrček, L. (2005). Integrated Handbook with Regard to Principles of Good Agricultural Practice. Prague, Opava: Ministry of Agriculture, Ekotoxa s.r.o.

Dwyer, J. (2016). Approaches to Revitalise Rural Economies and Communities - Reflections of a Policy Analyst. European Countryside, 8(2), 175-182, https://doi.org/10.1515/ euco-2016-0014

Eurostat (2011). Eurostat Database ef-ov-kvaa. Overview of Agricultural Holdings. Accessed 12/05/2017.

Firbank, L., Bradbury, R., McCracken, D., Stoate, C. (2013). Delivering Multiple Ecosystem Services from Enclosed Farmland in the UK. Agriculture, Ecosystems and Environment, 166, 65-75, https://doi.org/10.1016/j.agee.2011.11.014 
[IfLS] Institute for Rural Development Research (2012). Ex-post Evaluation of Rural

Development Programmes 2000-2006. Contract number 30-CE-0387013/00-01. Report for

Directorate-General Agriculture and Rural Development. Frankfurt/Main: John Wolfgang Goethe University.

Jongeneel, R., Bezlepkina, I., Aramyan, K., Dillen, K., Swales, V., Landgrebe, R., Meister, A., Varela Ortéga, C., Poux, X., Karaczun, Z., Winston, J. (2005). Product-Based Assessments to Link Compliance to Standards at Farm Level to Competitiveness. Deliverable for the study on Compliance and competitiveness of European agriculture (funded from FP6 Strep project). The Hague: Agricultural Economics Research Institute, Wageningen UR.

Jongeneel, R., Farmer, M., Mussner, R., de Roest, K., Meister, A., Varela Ortéga, C., Poux, X., Karaczun, Z., Winston, J. (2007). Compliance with Mandatory Standards in Agriculture. A Comparative Approach of the EU vis-à-vis the United States, Canada and New Zealand. Deliverable for the study on Compliance and competitiveness of European agriculture (funded from FP6 Strep project). The Hague: Agricultural Economics Research Institute, Wageningen UR.

Kazukauskas, A., Newman, C., Sauer, J. (2014). The Impacts of Decoupled Subsidies on Productivity in Agriculture: a Cross-Country Analysis Using Microdata. Journal of Agricultural Economics, 45(3), 327-336, https://doi.org/10.1111/agec.12068

Keenleyside, C., Allen, B., Hart, K., Baldock, D. (2012). Design and Implementation of AgriEnvironmental Policies: are Guidelines Feasible? In: Evaluation of Agri-Environmental Policies: Selected Methodological Issues and Case Studies. Paris: OECD Publishing, https:// doi.org/10.1787/9789264179332-4-en

Kowalczyk, A., Kuzniar, A., Kostuch, M. (2014). Analysis of Criteria for Delimiting Less Favoured Mountain Areas. Water and Land Development, 22(1), 17-24, https://doi.org/10.2478/ jwld-2014-0018

LEI (2010). Farm Viability in the European Union: Assessment of the Impact of Changes in Farm Payments. Report 2010-011. The Hague: LEI-DLO.

Loriz-Hoffmann, J. (2011). Vorschlaege der Kommission fur die Laendliche Entwicklungspolitik nach 2013 (anglicky). Lambach, Austria: Directorate-General Agriculture.

Madureira, L., Santos, J. L., Ferreira, A. C., Guimarães, H. (2013). Feasibility Study on the Valuation of Public Goods and Externalities in EU Agriculture. Ispra: Joint Research Centre.

Matthews, A. (2016a). The Potential Implications of a Brexit for Future EU Agri-Food Policies. EuroChoices, 15(2), 17-23, https://doi.org/10.1111/1746-692x.12128

Matthews, A. (2016b). Research for Agri Committee - the Future of Basic Supports. Report to the Policy Department B: Structural and Cohesion Policies, Agriculture and Rural Development. Brussels: European Parliament. ISBN 978-9284601912.

Meyers, W., Ziolkowska, J. (2012). Sustainable Development Strategies - Patterns, Policies and Challenges for the Agricultural Sector, in Cudlínová, E., Lapka, M., eds., An Environmental Society? Concepts, Policies, Outcomes. Prague: Karolinum Press. ISBN 978-8024620923.

Ministry of Agriculture (1998, 2004 to 2011). State of Agriculture Reports. [Retrieved 201602-11] Available at: http://eagri.cz/public/web/mze/ministerstvo-zemedelstvi/ vyrocni-a-hodnotici-zpravy/zpravy-o-stavu-zemedelstvi/

Ministry of Agriculture (2009). Annual Report on the Implementation of Rural Development Programme in 2007. Prague: Ministry of Agriculture. ISBN 978-8070847350.

Ministry of Agriculture (2016). Ex-post Evaluation of Rural Development Plan 2007-2013. Prague: Ireas s.r.o. 
Nadal-Romero, E., Lasanta, T., Cerdà, A. (2016). Integrating Extensive Livestock and Soil Conservation Policies in Mediterranean Mountain Areas for Recovery of Abandoned Lands in the Central Spanish Pyrenees. A Long-Term Research Assessment. Land Degradation and Development, 29(2), 262-273, https://doi.org/10.1002/ldr.2542

Nikodemus, O., Bell, S., Grine, I., Liepins, I. (2005). The Impact of Economic, Social and Political Factors on the Landscape Structure of the Vidzeme Uplands in Latvia. Landscape and Urban Planning, 70(1-2), 57-67, https://doi.org/10.1016/j.landurbplan.2003.10.005

OECD (2008). Czech Republic Country Report. Paris: OECD.

Pelucha, M., Kveton, V., Jilkova, J. (2013). Territorial Dimensions of Agro-Environmental Measures and LFA in Rural Development Policy in the Czech Republic. Land Use Policy, 34, 91-103, https://doi.org/10.1016/j.landusepol.2013.01.006

Pinto-Correia, T., Guerra, C. A. (2016). Linking Farm Management and Ecosystem Service Provision: Challenges and Opportunities for Soil Erosion Prevention in Mediterranean Silvo-Pastoral Systems. Land Use Policy, 51, 54-65, https://doi.org/10.1016/j. landusepol.2015.10.028

Rizov, M., Pokrivcak, J., Ciaian, P. (2013). CAP Subsidies and Productivity of the Farms. Journal of Agricultural Economics, 64(3), 537-557, https://doi.org/10.1111/1477-9552.12030

Rodrigo-Comino, J., Martínez-Hernández, C., Iserloh, T., Cerdà, A. (2017). The Contrasted Impact of Land Abandonment on Soil Erosion in Mediterranean Agriculture Fields. Land Use Policy, In press. doi: https://doi.org/10.1016/S1002-0160(17)60441-7

Rudow, K. (2014). Less Favoured Area Payments - Impacts on the Environment, a German perspective. Agricultural Economics, 60(6), 260-272, https://doi. org/10.17221/74/2013-agricecon

Rutz, C., Dwyer, J., Schramek, J. (2014). More New Wine in the Same Old Bottles? The Evolving Nature of the CAP Reform Debate in Europe, and Prospects for the Future. Sociologia Ruralis, 54(3), 266-284, https://doi.org/10.1111/soru.12033

Santos, J. L., Madureira, L., Ferreira, A. C., Espinosa, M., Gomez y Paloma, S. (2016). Building an Empirically-Based Framework to Value Multiple Public Goods of Agriculture at Broad Supranational Scales. Land Use Policy, 53, 56-70, https://doi.org/10.1016/j. landusepol.2015.12.001

Schmitzberger, I., Wrbka, T., Steurer, B., Aschenbrenner, G., Peterseil, J., Zechmeister, H. G. (2005). How Farming Styles Influence Biodiversity Maintenance in Austrian Agricultural Landscapes. Agriculture, Ecosystems and Environment, 108(3), 274-290, https://doi. org/10.1016/j.agee.2005.02.009

Tangermann, S. (2011). Basic Supports in the CAP Post 2013. Report to the Policy department B: Structural and Cohesion Policies, Agriculture and Rural Development. Brussels: European Parliament.

Tima s.r.o. (2010). Mid-term Evaluation of Rural Development Programme 2007-2013. Prague: Ministry of Agriculture.

Vrolijk H., de Bont, C., van der Veen, H., Wisman, J., Poppe, K. (2009). Volatility of Farm Incomes, Prices and Yields in the European Union. Report 2009-005. The Hague: LEI Wageningen UR.

Wrbka, T., Erb, K. H., Schulz, N. B., Peterseil, J., Hahn, C. O., Haberl, H. (2004). Linking Pattern and Process in Cultural Landscapes. An Empirical Study Based on Spatially Explicit Indicators. Land Use Policy, 21(3), 289-306, https://doi.org/10.1016/j.landusepol.2003.10.012 